\title{
MIC in Circulating Cooling Water System*
}

\author{
Ping Xu ${ }^{1,2}$, Zhaoyi Xu ${ }^{1}$, Jin Wang ${ }^{1}$, Yajun Zhang ${ }^{2}$, Li Zhang ${ }^{2}$ \\ ${ }^{1}$ School of Civil Engineering and Architecture, Beijing Jiaotong University, Beijing, China \\ ${ }^{2}$ Key Laboratory of Urban Stormwater System and Water Environment (Beijing University of \\ Civil Engineering and Architecture), Ministry of Education, Beijing, China \\ Email: xuping@bucea.edu.cn
}

Received January 22, 2012; revised February 28, 2012; accepted March 29, 2012

\begin{abstract}
MIC is one of the main problems of circulating cooling water system. The direct economic loss by MIC is about 300 to 500 billion dollars. It is good to understand MIC in order to control MIC. Source and species of microorganisms was introduced firstly. There are three kinds of microorganisms in the system, including bacteria, fungi and algae. Species of these microorganisms are shown in the paper. Then, mechanisms of MIC are analysed. Although there is no universal mechanism of MIC, MIC is still mainly an electrochemical corrosion in nature. Meanwhile, the mechanisms on SRB and iron bacteria are introduced in details. At last, several methods of microorganisms control are put forward in the paper.
\end{abstract}

Keywords: Circulating Cooling Water System; MIC; Microorganisms Species; Mechanism of MIC; Control Methods

\section{Introduction}

There are obvious advantages for microorganisms if they are attached to a solid surface. These accumulations of living matter are generally referred to as "biofilm" or "slime" [1]. The corrosion by existence or action of microorganisms in biofilm is called microbially influenced corrosion (MIC). According to statistics, MIC accounted for $20 \%$ in metal and building materials corrosion damages [2]. The direct economic loss by MIC is about 300 to 500 billion dollars [3].

In circulating cooling water system, $\mathrm{pH}$ is often 7.0 9.0, water temperature is during $20^{\circ} \mathrm{C}-40^{\circ} \mathrm{C}$, DO and nutrients are often enough. So favourable conditions provide a suitable environment for microorganisms growth. Some places such as cooling water intake tunnels, culverts, pump chambers and heat exchangers are often colonized by organisms. Microorganisms species in circulating cooling water system, microbial corrosion mechanisms and microorganisms control methods are introduced in the paper.

\section{Microorganisms Species in Circulating Cooling Water System}

\subsection{Sources}

There are two main ways that microorganisms enter into

\footnotetext{
${ }^{*}$ The paper are supported by two Chinese national grand projects for water pollution control: Integrative Technology and Demonstration on Reclaimed Water Utilized to Industry in Beijing 2009ZX07314-00904); Research Technology of and Demonstration on Urban Water onservation (2009ZX07317-005).
}

cooling water system. One is from makeup water and the other one is from air or rainwater. The numbers and species of microorganisms in circulating cooling water directly depended on the quality of the makeup water. When the system is makeup by groundwater or tap water, fewer microorganisms would grow. However, when recycled water is used to makeup the system, more microorganisms would be caused. Moreover, for the open-cycle cooling water system, microorganisms from the air also play an important role for propagating of organisms in the system. Airborne microorganisms, plant spores, dust and some of the harmful gases and other substances will enter into the system during the water falling from the cooling tower. The water could be polluted by the biological (mainly microorganisms) and non-biological (organic and inorganic impurities) substances.

\subsection{Species}

There are three kinds of microorganisms in industrial cooling water system, including bacteria, fungi and algae. Species of these microorganisms are shown in Table $\mathbf{1}$.

About $60 \%$ to $70 \%$ bacteria in cooling water are Pseudomonas and Aerogenes. Pseudomonas is one kind of mucus bacteria. Their existence is helpful for the formation of slime. Sulfate reducing bacteria (SBR) and iron bacteria are common corrosion-related bacteria. The optimum growth temperature of SRB is $20^{\circ} \mathrm{C}-30^{\circ} \mathrm{C}$. However, SRB still can survive in high temperature with $55^{\circ} \mathrm{C}$ $-60^{\circ} \mathrm{C}$ and in wide $\mathrm{pH}$ range during 5.0 - 10. Because of its special anaerobic, SRB only survives below the aero- 
bic bacteria and other corrosion deposits. Iron and manganese compounds are very important for iron bacteria growth. Iron bacteria will grow well during the concentration of total iron in $1-6 \mathrm{mg} / \mathrm{L}$. When the ratio of organic and iron concentration lie in an appropriate range, higher organic will lead to more iron bacteria. It is also beneficial for the growth of iron bacteria in weak acid water with the presence of $\mathrm{CO}_{2}$. Suitable temperatures are different for different species of iro bacteria. Some can survive in the temperature as low as $5^{\circ} \mathrm{C}$, while others like higher temperature during $25^{\circ} \mathrm{C}-27^{\circ} \mathrm{C}$ [4].

There are two types of fungi, including molds and yeasts living in cooling water system. They could often be found in cooling equipment, wood components, heat exchanger and the pool wall. Cyanobacteria, green algae and diatoms are common algae in cooling water. Among air, water, sunlight and nutrients, sunlight is most important for algae growth. These algae could be grown in shine or some places exposed in sunshine, such as cooling tower, water pool, interface of water mains, etc.

\section{Mechanisms of Microbially Influenced Corrosion}

\subsection{Electrochemical Nature of Corrosion}

Corrosion of metal in cooling water system is associated with an electrochemical reaction, as shown in Figure 1.

Table 1. Microorganisms in cooling water system.

\begin{tabular}{|c|c|c|c|}
\hline Species & $\mathrm{T}\left({ }^{\circ} \mathrm{C}\right)$ & $\mathrm{pH}$ & Problems \\
\hline $\begin{array}{l}\text { Aerobic bacteria } \\
\text { capsule type }\end{array}$ & $20-40$ & $4.0-8.0$ & $\begin{array}{l}\text { forming bacterial slime } \\
\text { mainly, causing stoppage }\end{array}$ \\
\hline $\begin{array}{l}\text { Aerobic sulfur } \\
\text { bacteria }\end{array}$ & $10-37$ & $0.6-7.8$ & causing corrosion \\
\hline $\begin{array}{l}\text { Sulfate-reducing } \\
\text { bacteria }\end{array}$ & $0-70$ & $5.5-9.0$ & $\begin{array}{l}\text { producing hydrogen } \\
\text { sulfide, causing corrosion }\end{array}$ \\
\hline Iron bacteria & $0-40$ & $6-9.5$ & $\begin{array}{l}\text { formation of iron } \\
\text { hydroxide in the cell } \\
\text { protective shell around, } \\
\text { causing stoppage }\end{array}$ \\
\hline Filamentous fungi & $0-38$ & $2-8$ & $\begin{array}{l}\text { forming bacterial slime, } \\
\text { causing stoppage }\end{array}$ \\
\hline Yeast & $0-38$ & $2-8$ & $\begin{array}{c}\text { causing stoppage } \\
\text { Discoloration of water and } \\
\text { wood }\end{array}$ \\
\hline Chlorella & $30-35$ & $5.5-8.9$ & $\begin{array}{l}\text { affect the appearance, } \\
\text { causing stoppage }\end{array}$ \\
\hline $\begin{array}{l}\text { Blue-green algae } \\
\text { (blue pigment layer) }\end{array}$ & $35-40$ & $6.0-8.9$ & $\begin{array}{l}\text { affect the appearance, } \\
\text { causing stoppage }\end{array}$ \\
\hline $\begin{array}{l}\text { Diatoms (brown } \\
\text { pigment-containing } \\
\text { layer) }\end{array}$ & $17-36$ & $5.5-8.9$ & $\begin{array}{l}\text { affect the appearance, } \\
\text { causing stoppage }\end{array}$ \\
\hline
\end{tabular}

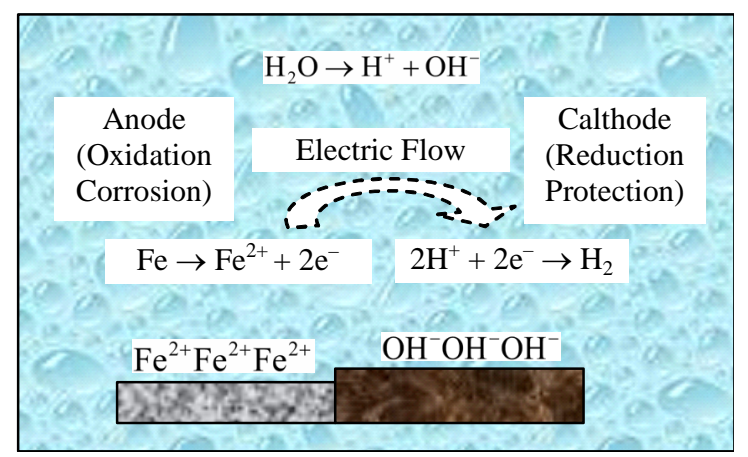

Figure 1. Electrochemical reaction of corrosion cell.

In the corrosion cell, a neutral iron atom loses two electrons and becomes an iron ion, $\mathrm{Fe}^{2+}$ in solution. The electrons flow through the metallic path to the cathode. They combine with two positively charged hydrogen ions and result molecule of hydrogen escapes as a gas [5]. As a depolarizing agent, reduction of $\mathrm{H}^{+}$accelerates cathode reaction of corrosion battery. However, due to high overpotential, precipitation of hydrogen is very difficult. So adsorbed hydrogen atoms accumulate on the surface and inhibite cathode reaction.

\subsection{Microbially Influenced Corrosion}

In 1910, Gaine proposed firstly a concept that microorganisms involved in metal corrosion. Moreover, he separated Gallionella from the corrosion products of an underground pipe [6]. Dutch scholar Von Wolzogen Kuhr had done a lot researches on MIC since 1922. He proposed classical cathodic depolarization theory of SRB corrosion firstly [7]. In recent year, many scholars such as Beech, Flemming and Wingender, Viedela, Herrera and others, studied the mechanism of microbial corrosion deeply [8-10].

Microorganisms could influence the corrosion of metals 1) by consuming oxygen, the cathodic reactant; 2) by increasing the mass transport of the corrosion reac- tants and products, therefore changing the kinetics of the corrosion process; 3) by generating corrosive substances; and 4) by generating substances that serve as auxiliary cathodic reactants [11].

SRB corrosions are considered main type of MIC. SRB are obligate anaerobes, which can utilize sulphate as the terminal electron acceptor for their respiratory metabolism, thereby producing significant amounts of sulphide [12].Through the action of active hydrogenase enzyme, these bacteria can prevent the accumulation of atomic or molecular hydrogen at the cathode, thus impeding cathodic polarization [13].

$$
\begin{gathered}
\mathrm{SO}_{4}^{2-}+8 \mathrm{H}^{+}+8 \mathrm{e} \stackrel{\text { hrdrogenase }}{\longrightarrow} \mathrm{S}^{2-}+4 \mathrm{H}_{2} \mathrm{O}+\text { engery } \\
\mathrm{S}^{2-}+2 \mathrm{H}^{+} \rightarrow \mathrm{H}_{2} \mathrm{~S}
\end{gathered}
$$


Another theory considers the sulfides of iron and hydrogen are effective cathodic depolarizing agents [13].

Corrosion products, FeS, are produced at the anode as a result of the reaction of anodic production, $\mathrm{Fe}^{2+}$, and Cathodic production, $\mathrm{S}^{2-}$. Sulfide also promotes ionization of many metals and therefore accelerates the anodic reaction.

$$
\begin{aligned}
& 4 \mathrm{Fe} \rightarrow 4 \mathrm{Fe}^{2+}+8 \mathrm{e} \\
& \mathrm{Fe}^{2+}+\mathrm{S}^{2-} \rightarrow \mathrm{FeS}
\end{aligned}
$$

Iron oxidizing bacteria can promote the corrosion of iron and stainless steel pipes in aerobic environments. The bacteria use the ferric oxide as an alternate terminal electron acceptor and oxidize ferrous iron to ferric iron, as shown in Figure 2.

Ferric hydroxides and other metal salts form tubercles accumulate on the inner surface of the pipes. The area beneath the deposit becomes anaerobic due to the oxygen diffusion barrier created by the precipitate and the respiratory activities of the bacteria. One isolate depolarized the anode. The reaction at the cathode was unaffected by the bacterium. Bacteria that have been commonly found in tubercles over pits in stainless steel include Sphaerotilus natans, Gallionella and Siderocapsa [13].

Moreover, many biofilm cover the metal surface in uneven distribution manner. Areas covered with biofilm exhibit higher oxygen concentrations and become anodic, while those with less biofilm exhibit higher oxygen concentrations and become cathodic. As a result, anodic and cathodic areas are fixed at the metal surface. Corrosion may result eventually.

\section{Methods of Microorganisms Control}

There are three kinds of method to control microorganisms in circulating cooling water system: physical, chemical and biological method.

\subsection{Physical Method}

Filtration is a conventional approach to control regeneration of microorganisms by removing suspended solid from makeup water and cooling water. Recently, method of physical field control causes more attention, including e-field, magnetic treatment, pulsed electric field and high

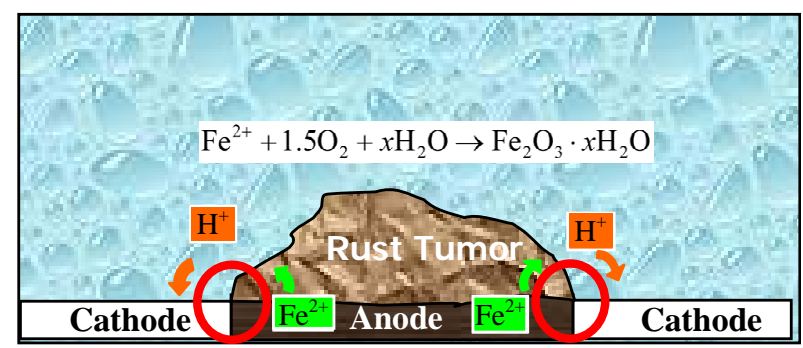

Figure 2. Corrosion of Iron bacteria. pressure static method. For E-field method, water is electrified directly to produce micro-current. In electric field, current and electrochemical action changes the structure of microbial cells and water molecular, thus inhibiting the growth of microorganisms. There has no generally accepted mechanism of magnetic treatment method now, which can be interpreted as electromagnetic induction, crystal, resonance to achieve the purpose of the remove scaling, bacteria, algae [14]. Pulsed electric field method is to inactivate the microorganism cell ion and avoid bacteria deposition on the surface by using $20 \mathrm{kV}$ highvoltage pulsed electric field. Electrostatic water treatment method was first proposed by several engineers from United States. This method can remove scaling, bacteria, algae and reduce corrosion.

In addition, many studies reported that ultrasonic catalytic $\mathrm{TiO}_{2}$ was effective to water sterilization [15]. However, the method is seldom used to the circulating cooling water system for biofouling control. Bott studied the ultrasonic treatment of cooling water, results showed that the ultrasonic could control biofilm formation and removal the formed biofilm when the speed was $1 \mathrm{~m} / \mathrm{s}$ [16].

\subsection{Chemical Method}

Biocide is a most widely used method of chemical control. According to the mechanism, biocides can be divided into two categories, oxidized and non-oxidizing. Oxidizing biocides are generally strong oxidants. The mechanism is to kill microorganisms by oxidizing their enzymes which are very important in metabolism. The biocides include chlorine biocides, bromine biocides, fungicides peroxide, ozone and so on. Non-oxidizing biocide kills microorganisms not in oxidize way, but the way of directly acting on their specific parts of the body [16]. The biocides include isothiazole lin ketone, chlorophenols, quaternary ammonium, sulfate, organic tin compounds, allicin and so on.

\subsection{Biological Method}

Enzyme treatment method is an environmentally friendly approach. Studies show that A2 amylase, trypsin, cellulase have significant effect to inhibit biofouling. Moreover, no toxic substances are produced in circulating water system by using enzyme treatment agents [14].

Phage is also called bacteria viruses. Phage can invade into host cells and propagation quickly. Finally host cells will autolyse and release hundreds of phage [14]. Therefore, a small amount of phage can control a lot of bacteria and prevent the formation of slime in cooling water system.

\section{Conclusions}

In conclusion, sources of microorganisms mainly come 
from makeup water. It is very important to keep high quality of makeup water. In cooling water system, microorganisms often accumulate on the surface and can influence the corrosion of metals by several ways. It should be noted that although there is no universal mechanism of MIC, but in nature it is still mainly an electrochemical corrosion.

In recent decades, more and more attentions have been attracted by the phenomena, mechanisms, monitoring and control methods of MIC. New technologies are used to explore MIC, such as natural fluorescence detection, BIOX electrochemical detection, infrared monitor and ATP assay et al. Computer technology is also used to establish a comprehensive model to predict and control MIC.

\section{Acknowledgements}

The research was supported by two Chinese national grand projects for water pollution control: Integrative Technology and Demonstration on Reclaimed Water Utilized to Industry in Beijing (2009ZX07314-009-04); Research Technology of and Demonstration on Urban Water-Conservation (2009ZX07317-005).

\section{REFERENCES}

[1] T. Reg Bott, “Industrial Biofouling,” Elsevier, Lobdon, 2011.

[2] H.-C. Flemming, "Economical and Technical Overview," In: E. Heitz, H.-C. Flemming and W. Sand, Eds., Microbially Influenced Corrosion of Materials, Springer-Verlag, Heidelberg, 1996. doi:10.1007/978-3-642-80017-7_2

[3] D. Walsh, D. Pope, M. Danford, et al., "The Effect of Microstructure on Microbiologically Influenced Corrosion," Journal of the Minerals Metals and Materials Society, Vol. 45, No. 9, 1993, pp. 22-30. doi:10.1007/BF03222429

[4] P. Zhang, "Research on Biofouling Growth Characteristic and Control in the Circulating Cooling Wate System," M.Sc. Thesis, University of Petroleum of China, Beijing, 2010.
[5] P. R. Puckorius, "Water Corrosion Mechanisms," Water Treatment, Vol. 5, 1999, pp. 57-61.

[6] G. H. Booth and A. K. Tiller, "Cathodic Characteristics of Mild Steel in Suspensions of Sulfa Reducing Bacteria," Corrosion Science, Vol. 8, No. 8, 1968, pp. 583-600. doi:10.1016/S0010-938X(68)80094-0

[7] W. P. Iversion, "Direct Evidence for the Cathodic Depolarization Theory of Bacterial Corrosion,” Science, Vol. 151, No. 3713, 1966, pp. 986-988. doi:10.1126/science.151.3713.986

[8] I. B. Beech, J. A. Sunner and K. Hiraoka, "Microbe-Surface Interactions in Biofouling and Biocorrosion Processes”, International Microbiology, Vol. 8, No. 3, 2005, pp. 157-168.

[9] H. A. Videla and L. K. Herrera, "Microbiologically Influenced Corrosion: Looking to the Future,” International Microbiology, Vol. 8, No. 3, 2005, pp. 169-180.

[10] W. Wang, J. Wang, H. Xu and X. Li, "Some Multidisciplinary Technique Used in MIC Studies,” Materials and Corrosion, Vol. 57, No. 7, 2006, pp. 531-537. doi:10.1002/maco.200503951

[11] Z. Lewandowski and H. Beyenal, "Mechanisms of Microbially Influenced Corrosion. Springer Series on Biofilms," Marine and Industrial Biofouling, Vol. 4, No. 1, 2009, pp. 35-64. doi:10.1007/978-3-540-69796-1_3

[12] W. A. Hamilton, "Sulphate Reducing Bacteria and Their Role in Biocorrosion," Biofouling and Biocorrosion in Industrial Water Systems, Springer-Verlag, Berlin Heidelberg, 1990, pp. 187-193.

[13] G. Gill, "What Is Biocorrosion,” Biofouling and Biocorrosion in Industrial Water Systems, Springer-Verlag, Berlin Heidelberg, 1990, pp. 155-164.

[14] J. Y. Luo, H. Z. Wang and P. Xu, "Control the Impact of Microorganisms When Reclaimed Water Reuse for Circulating Cooling Water System,” Water and Wastewater Engineering, Vol. 34, 2008, pp. 213-216.

[15] Z. H. Liu and B. Dong, "Biofouling Control in Circulating Cooling Water System,” China Water and Wastewater, Vol. 24, No. 12, 2008, pp. 22-26.

[16] X. Mi, "Experimental Researches on Biological Slime Control of Cooling Water System of Power Plants," M.Sc. Thesis, Wuhan University, Wuhan, 2005. 